\title{
Review of Poultry Production and Poultry Vaccine Manufacture in Nepal
}

\author{
Uddab Poudel ${ }^{a}$, Umesh Dahal ${ }^{b}$, and Santosh Dhakal ${ }^{\text {,* }}$ \\ ${ }^{a}$ Department of Veterinary Microbiology and Parasitology, Agriculture and Forestry University (AFU), Rampur,44209, Nepal \\ ${ }^{b}$ Nepal Livestock Sector Innovation Project, Department of Livestock Services, Hariharbhawan, Lalitpur, 44700, Nepal \\ ${ }^{c}$ W. Harry Feinstone Department of Molecular Microbiology and Immunology, Johns Hopkins Bloomberg School of Public Health, Baltimore, MD 21205 , \\ USA
}

\begin{tabular}{l} 
M A N U S C R I P T I \\
\hline Article history: \\
Received 28 Nov 2020 \\
Received in revised form 1 \\
Accepted 1 May 2021 \\
\hline Keywords: \\
Mean and egg production \\
Poultry diseases \\
Poultry industry in Nepal \\
Poultry vaccines
\end{tabular}

\section{Citation:}

Poudel, U., Dahal, U., \& Dhakal, S. (2021). Review of poultry production and poultry vaccine manufacture in Nepal. Global Journal of Agricultural and Allied Sciences, 3(1), 1-7.

\section{Introduction}

Poultry industry is one of the fastest growing agriculture industries in the world. Over the last few decades, poultry industry has undergone tremendous adjustments, leading to the continuous growth of this sector (Gerber, Opio, \& Steinfeld, 2007). According to the Food and Agriculture Organization (FAO) statistics, global poultry population in the year 2016 was more than 23 billion which was 5 times higher than the poultry population 50 years ago (Mottet \& Tempio, 2017). Human population growth, rapid urbanization, and increase in purchasing capacity of the individuals are the factors driving the increased demand for poultry products (Mottet \& Tempio, 2017). Poultry meat productivity is expected to increase with more than $2.5 \%$ per annum from $1999 / 01$ to 2030 and by $1.5 \%$ per annum from 2030 to 2050 , whereas demand is expected to increase by $2.6 \%$ and $1.5 \%$, respectively, during the same time period (FAO, 2006). In accordance, world poultry meat production soared from 9 to 122 million tonnes between the years 1961 and 2017 while egg production increased from 15 to 87 million tonnes (FAO, 2020a). The consumption of poultry products has tremendously increased in the last

\footnotetext{
* Corresponding author. E-mail address: santoshdhakal88@gmail.com
}

three decades and the poultry market is likely to keep growing in the future as well (OECD-FAO, 2011).

Foods from the animal source are highly beneficial for all age groups for nutrition and good health, as they are rich in vitamins and micronutrients (Murphy \& Allen, 2003). Poultry meat, both muscle and organ meat, and eggs are one of the best sources to supply valuable dietary proteins, vital vitamins, and minerals. Poultry products are rich in bioavailable nutrients, contain low fat and cholesterol, and are available at a cheaper price compared to the red meat (Arihara, 2006; Petracci, Bianchi, Mudalal, \& Cavani, 2013). Highly bioavailable nutrients supplied through poultry products are more important particularly for infants and young children with limited gastric volume for proper physical and mental development; pregnant and lactating women who have increased nutrient requirement for fetal development and to reduce mortality among children and young infants; elderly people who have decreased intestinal absorption capacity; and also for ill and sick people for speedy recovery (Farrell, 2013; Olaoye, 2011). In this review, we have summarized the current status of poultry production, disease burden, and poultry vaccine production in Nepal. 


\section{Contribution of Poultry Industry in the National Economy}

In Nepal, two-thirds of its population residing within the country are directly or indirectly engaged in agriculture (FAO, 2020b). Livestock farming is an important aspect of agricultural business in Nepal which has been continuously growing in the past decade (Poudel, Dahal, Upadhyaya, Chaudhari, \& Dhakal, 2020). Agriculture sector has $27.1 \%$ contribution in the national gross domestic product (GDP) of Nepal while the poultry subsector alone has estimated 4\% contribution in GDP (FAO, 2014a; MoALD, 2020). Poultry industry has created direct and indirect employment opportunities for more than 150,000 people (Table 1). Investment in the poultry sector is about Rs. 115 billion (around US \$1.1 billion), and the investment is likely to increase further in the coming decade leading to the growth of this sector and greater contribution towards national economy (Table 1). Backyard poultry plays a pivotal role in the rural socioeconomic system as majority households in rural villages raise poultry as a source of cash income (Spradbrow, 1992). Small scale poultry farming is popular in rural and peri-urban areas of Nepal as it involves small capital investment, can be managed by women and younger children, requires smaller areas, serves as the protein source for the family, and provides extra income which can be invested in other household requirements (Acharya \& Kaphle, 2015). According to the commercial poultry survey carried out in 2014-2015 in Nepal, the overall transaction in poultry sector was Rs. 33.72 billion (US $\$ 0.33$ billion) where broiler meat had highest transaction of about Rs. 20.52 billion ( $60.9 \%$, US $\$ 0.2$ billion), followed by eggs, Rs. 9.13 billion (27.1\%, US $\$ 90$ million); chicks, Rs.3.61 billion (10.7\%, US \$30 million); and poultry manure, Rs.453.72 million (1.3\%, US $\$ 4.53$ million) (CBS, 2016). Poultry manure is used not only for agriculture crops and vegetables but also as the feed for fish in the integrated fish-poultry farming system where poultry are raised on top of the pond as part of the integrated system popular in Asian countries (FAO, 2014b). Chitwan district, in Bagmati Province, can be considered as the poultry capital of Nepal as it holds highest number of poultry farms, population, and productivity (Table 1). Nepal has no long history of poultry export but recently has started export of broiler meat and eggs to Bhutan. Rapid development in the poultry industry makes Nepal self-reliant in production of meat and eggs within the country (CBS, 2016). At present, both the investment and market and supply chain of poultry have drastically increased which ensure the availability of poultry meat and eggs in every local market of Nepal (CBS, 2016). On 25th March 2021, Nepal announced itself self-sufficient in egg and meat production and progresses towards self- sufficiency in milk as well (Prasain, 2021).

\section{Poultry Population and Productivity in Nepal}

According to the Ministry of Agriculture and Livestock Development (MoALD) of Nepal, in 2017-2018, there were more than 72 million fowls, 400,000 ducks, 12 million laying hens, and 186,000 laying ducks in Nepal (Figure 1). The population of chicken increased by more than 195\% within a decade with average annual growth rate of around $19.5 \%$ while that of the ducks was around $5.62 \%$ with annual growth of $0.56 \%$ (Poudel et al., 2020). Along with the commercial poultry, rearing of indigenous Nepalese poultry breeds was also increased in the rural and village areas of Nepal. These local breeds are hardy in nature and adapt to the harsh environment and are resistant to many pathogens (FAO, 2014a).
Exotic breeds, compared to the local breeds, are mostly reared under intensive management systems with adequate housing, nutrition, and health control. The exotic breeds commercially popular in Nepal include Cobb

Table 1. Current status of poultry industry in Nepal (CBS, 2016; FAO, 2014a; Singh, 2018; MoALD, 2020).

\begin{tabular}{|c|c|}
\hline Poultry scenario & Number \\
\hline GDP contribution by agriculture & $27.1 \%$ \\
\hline GDP contribution by poultry & $4 \%$ \\
\hline AGDP contribution by poultry & $8 \%$ \\
\hline Investment in poultry sector & $\begin{array}{l}\text { Rs. } 115 \text { billion (around US } \$ 1.1 \\
\text { billion) }\end{array}$ \\
\hline Import & $\begin{array}{l}\text { 1,091,730 ( } 985,503 \text { broiler and } \\
\text { 107,894-layer parent stock in } \\
\text { 2011/2012) }\end{array}$ \\
\hline Export & $\begin{array}{l}\text { No history of export but recently } \\
\text { started to export broilers and eggs to } \\
\text { Bhutan }\end{array}$ \\
\hline Contribution in total meat yield & $17.4 \%$ \\
\hline $\begin{array}{l}\text { World ranking in chicken meat } \\
\text { production }\end{array}$ & 112 \\
\hline World ranking in egg production & 92 \\
\hline Feed industries & 111 \\
\hline Registered poultry farm & 16,000 \\
\hline Hatcheries (2018-2019) & 320 \\
\hline Medicine dealers and sub-dealers & 2,800 \\
\hline Meat processors & 9 \\
\hline Egg tray and cartoon industries & 16 \\
\hline Per capita chicken meat consumption & 5.7 \\
\hline Per capita chicken egg consumption & 61 \\
\hline Broiler chicken & 65 million \\
\hline Layers chicken & 12 million \\
\hline Total egg production per day & 2.9 million \\
\hline Egg production per bird & $280-300$ \\
\hline Total meat production per day & 350 tons \\
\hline Overall growth in poultry & $2.04 \%$ per year \\
\hline \multicolumn{2}{|l|}{ Broiler farm (2014-2015) } \\
\hline Up to 1000 & 6,144 \\
\hline $1001-5000$ & 12,036 \\
\hline $5001-10,000$ & 1,818 \\
\hline$>10,000$ & 472 \\
\hline \multicolumn{2}{|l|}{ Layers farm (2014-2015) } \\
\hline Up to 1000 & 426 \\
\hline $1001-5000$ & 692 \\
\hline $5001-10,000$ & 168 \\
\hline$>10,000$ & 131 \\
\hline Employees & $\begin{array}{l}150,000 \text { directly and many more } \\
\text { indirectly }\end{array}$ \\
\hline Broiler production & 2.5 million per week \\
\hline Layers production & 118,208 per week \\
\hline Koilers production & 250,000 per week \\
\hline New sectors in poultry industry & Ostrich, Turkey, and Quail \\
\hline Feed production & 3,000 MT per day \\
\hline Annual feed industry growth & $8-10 \%$ \\
\hline Large scale pellet feed industry & 46 \\
\hline Investment in feed industry & Rs. 40 billion (US $\$ 0.4$ billion) \\
\hline Feed type & Mash feed and pellet feed \\
\hline $\begin{array}{l}\text { District with highest number of poultry } \\
\text { farms (2014-2015) }\end{array}$ & Chitwan $(1,920)$ \\
\hline $\begin{array}{l}\text { District with highest broiler production } \\
(2014-2015)\end{array}$ & Chitwan (5.3 million; 10\%) \\
\hline $\begin{array}{l}\text { District with highest egg production } \\
(2014-2015)\end{array}$ & Chitwan ( 0.8 billion; $68 \%$ ) \\
\hline
\end{tabular}


100, Cobb 500, Venn Cobb, Cobb Avian, Lohman Indian River, Hubbard Flex, Dominant CZ, Kasila, Bovans brown, B.V. 380, Hyline brown, Lohman brown, H\&N Nick brown, Hisex and Isa brown (FAO, 2014a).

Nepal is ranked 112th in meat production and 92nd in poultry egg production in the world (FAO, 2014a; Singh, 2018). There are more than 1,400 commercial layer farms and more than 20,000 commercial broiler farms in Nepal (Table-1). Poultry sector has supplied about $17.4 \%$ of total animal protein in Nepal. Chickens have contributed more than $99 \%$ of total poultry meat supply while ducks contributed the rest (Figures 2-3). Likewise, chickens contributed about $99.2 \%$ (1.49 billion) of total egg production of the country and ducks did the remaining (14.24 million). Per capita Nepalese population consumes $5.7 \mathrm{~kg}$ chicken meat and $3.66 \mathrm{~kg}$ (i.e., around 61) eggs annually which is far below the global average per capita consumption of $14.1 \mathrm{~kg}$ meat and $8.9 \mathrm{~kg}$ eggs (Mottet \& Tempio, 2017; Singh, 2018). This data indicates the need for increasing poultry productivity at cheaper price to address this consumption gap (CBS, 2016).

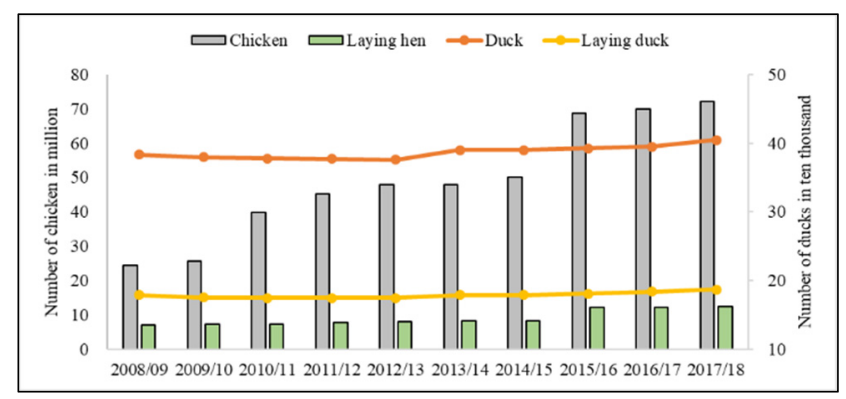

Figure 1. Trend of poultry population in Nepal (2008/09-2017/18) (MoALD, 2020).

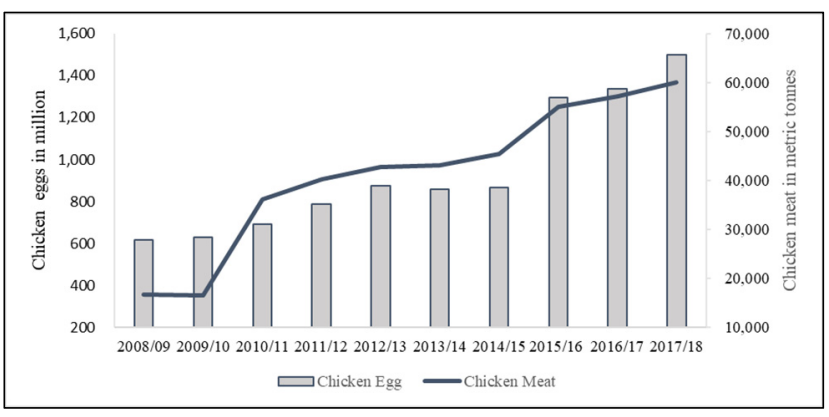

Figure 2. Trend of chicken meat and egg production in Nepal (2008/09 - 2017/18) (MoALD, 2020).

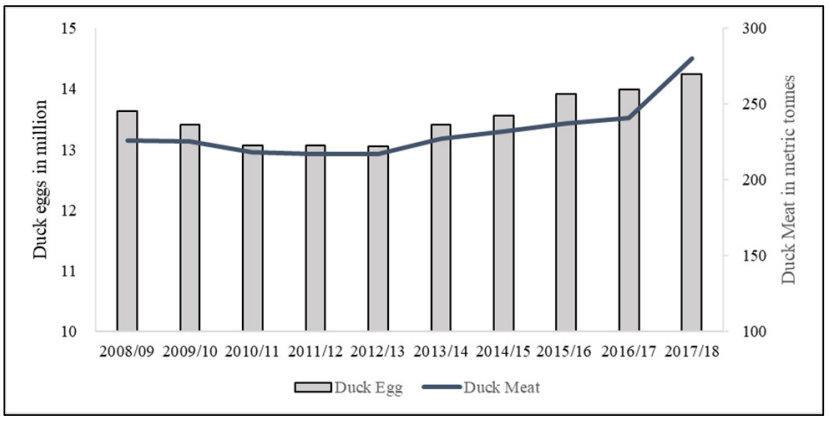

Figure 3. Trend of duck meat and eggs production in Nepal (2008/09 - 2017/18) (MoALD, 2020).

\section{Challenges Faced by the Poultry Industry in Nepal}

Though the number of birds and productivity is increasing, poultry sector in Nepal faces many challenges. First and foremost, the cost of per unit production of poultry is high due to costly raw feed materials and inefficient marketing structure (Dhakal, Joshi, Karn, Bhusal, \& Acharya, 2019). More than $75 \%$ cost of production is attributed to feed and treatments (Sharma, 2010). Nepal is heavily reliant on poultry feed ingredients, especially for maize as the energy source and soybean, sunflower, and meat and bone meals (MBM) as protein sources. Around 0.55 million tonnes of maize are utilized for poultry feed per annum of which only 35\% is domestic production. Almost $99 \%$ of protein sources are imported including around 180,000 tonnes of soybean meal, and around 27,000 tonnes of sunflower and MBM per year. On average Rs. 1.8 billion per year is invested to import poultry feed supplement (Singh, 2018). Lower optimum productivity of eggs and higher mortality of birds due to periodic outbreak of various infectious diseases add another layer of challenges in poultry industry (Osti, Bhattarai, Chaudhary, \& Singh, 2017). Poor biosecurity measures, unavailability of well-equipped disease diagnosis facilities, lack of welltrained technical manpower, and inappropriate use of antibiotics leading to antibiotic resistance constitute other major problems of poultry farming in Nepal (Acharya \& Kaphle, 2015). Lack of proper regulatory mechanisms for fixing market price based on production cost results in a highly fluctuating market value of chicken eggs and meats which can lead to huge economic burden among farmers (Acharya \& Kaphle, 2015). The lower production cost of poultry in India, open border, and lack of enforceable regulations and quarantine facilities lead to smuggling of poultry and poultry products in Nepal. This illegal import results in unhealthy competition with the in-country production system while raising the risk of transmission of various poultry pathogens. The porous border with neighboring country, weak epidemiological investigations, poor monitoring and quarantine, and unavailability of efficient drugs and vaccines are primarily responsible for endemicity of many poultry-related bacterial, viral and parasitic diseases in Nepal (Acharya \& Kaphle, 2015; Dhakal et al., 2019).

There were number of outbreaks of the nine World Organization for Animal Health (OIE)-listed poultry diseases in Nepal, reported from both the commercial and backyard poultry enterprises (VEC, 2018). The outbreaks of coccidiosis, fowl pox, infectious bursal disease (IBD) and Newcastle disease (ND) were more frequent than other diseases (Table 2). Maximum death was caused by IBD (36.68\%), followed by coccidiosis (23.99\%) and ND (18.51\%). Besides these OIE-listed pathogens, several other pathogens also impact the poultry industry in Nepal. While studying the case flow of Central Veterinary Laboratory (CVL), Kathmandu, Nepal for a period of one year, Gompo et al. (2019) observed that there were 2,271 total poultry cases registered where colibacillosis $(26 \%)$, mycotoxicity $(13 \%)$, ascites $(10 \%)$, chronic respiratory disease (CRD, $9 \%)$, IBD (7\%), ND (7\%), avian influenza (1\%), and coccidiosis (1\%) contributed mainly while remaining $21 \%$ cases were non-specified. Colibacillosis, caused by Escherichia coli, is the most common cause of bacterial infection in poultry farms in Nepal which is associated with poor farm hygiene (CVL, 2015; Gautam, Devekota, \& Thapaliya,, 2017; Shrestha \& Shrestha, 2020). Mycotoxicosis is another leading poultry disease caused by ingestion of fungal aflatoxin B1 and B2 having higher incidence in the pre-monsoon and monsoon seasons (Ae et al., 2007; Aryal \& Karki, 2009; Gompo et al., 2019). The incidence of ascites is also higher, and the maximum occurrence is observed in winter season since the farmer try to keep their poultry warm in poorly ventilated housing system and thus the low oxygen availability 
leads to the development of ascites (Gompo et al., 2019; Gupta, 2011; Shrestha \& Shrestha, 2020). In summer and winter months, poultry are mainly infected by CRD (Rajkumar, Reddy, \& Tech, 2017). Besides the economic loss in the poultry sector, certain poultry pathogens including avian influenza virus, Salmonella and Escherichia coli, also possess the risk of transmission to humans (Dale \& Brown, 2013). In March 2019, first human death due to avian influenza A virus subtype H5N1 was reported from Nepal (Shrestha, 2019).

Table 2. World Organization for Animal Health (OIE)-listed poultry disease outbreaks in Nepal in 2018 (VEC, 2018).

\begin{tabular}{|c|c|c|c|c|c|c|c|c|}
\hline \multirow{2}{*}{$\begin{array}{l}\text { Disease Name } \\
\text { Coccidiosis }\end{array}$} & \multicolumn{2}{|c|}{ Outbreak } & \multicolumn{2}{|c|}{ Susceptible } & \multicolumn{2}{|c|}{ Affected } & \multicolumn{2}{|l|}{ Dead } \\
\hline & 583 & $48.62 \%$ & 68272 & $5.54 \%$ & 168442 & $30.33 \%$ & 9543 & $23.99 \%$ \\
\hline Fowl pox & 252 & $21.01 \%$ & 11332 & $0.92 \%$ & 11771 & $2.12 \%$ & 766 & $1.92 \%$ \\
\hline Infectious bursal disease & 116 & $9.67 \%$ & 183567 & $14.91 \%$ & 234848 & $42.29 \%$ & 14586 & $36.68 \%$ \\
\hline Newcastle disease & 90 & $7.50 \%$ & 901866 & $73.27 \%$ & 74986 & $13.50 \%$ & 7363 & $18.51 \%$ \\
\hline Fowl typhoid & 55 & $4.58 \%$ & 1616 & $0.13 \%$ & 14809 & $2.66 \%$ & 889 & $2.23 \%$ \\
\hline Pullorum disease & 43 & $3.58 \%$ & 4789 & $0.38 \%$ & 17850 & $3.21 \%$ & 1206 & $3.03 \%$ \\
\hline Fowl cholera & 30 & $2.50 \%$ & 2088 & $0.16 \%$ & 11851 & $2.13 \%$ & 824 & $2.07 \%$ \\
\hline Avian infectious bronchitis & 27 & $2.25 \%$ & 32030 & $2.60 \%$ & 17540 & $3.15 \%$ & 1477 & $3.71 \%$ \\
\hline Highly pathogenic avian influenza & 3 & $0.25 \%$ & 25254 & $2.05 \%$ & 3110 & $0.56 \%$ & 3110 & $7.82 \%$ \\
\hline
\end{tabular}

\section{Poultry Related Policies and Gaps}

Poultry is the leading industry of Nepal and has tremendous capability to boost the country's economy. However, the national policies need to be updated to bridge the developmental gaps. Animal Health and Livestock Service Act 2055 (1999 AD) prioritizes to systematize and develop the animal husbandry business and to provide necessary arrangement related to healthy production, sale, distribution, export and import of animal products or animal production inputs. However, there is still no proper implementation and regulation of Poultry Policy 2068 (2011 AD) and Animal Slaughterhouse and Meat Inspection Act 2055 (1999 AD). Bird Flu Control Order, 2064 (2007 AD), which is specifically aimed to control bird flu in the country by providing the compensation to the farmer is in place. In addition, Government of Nepal provides $75 \%$ premium of insurance and only $25 \%$ premium cost is paid by the farmer for livestock and poultry insurance (DLS, 2021). There is still lack of common interest or knowhow in different poultry related unions, federations, associations, and institutions for the development of poultry sector, specially making it selfreliant on raw materials and therapeutics. Government of Nepal should formulate integrated national livestock and poultry policy to cope with current changing national and international environments that can sustainably increase diversification, commercialization, and competitiveness of the poultry sector (Pradhanang et al., 2015).

\section{Poultry Vaccine Production in Nepal}

Vaccines for veterinary use include inactivated/killed vaccines; liveattenuated vaccines; toxoids; recombinant subunit vaccines; RNA/DNAbased vaccines; and vectored-vaccines (McVey \& Shi, 2010). Livestock vaccine production in Nepal began in 1960s while the poultry vaccine production was started from 1968 (Poudel et al., 2020). At first, ND F1 strain, ND R2B strain and fowl pox vaccines were produced in Nepal (Gautam, Ghimire, Shrestha, \& Gautam, 2018). The severe outbreak of IBD in 1996 demanded for the production of IBD vaccine and hence its production was started in 1998 (Poudel et al., 2020). ND Lasota strain vaccine production was also started in 1998 to protect birds from velogenic strain of ND and this vaccine was well accepted as it was delivered through the drinking water. Traditionally, poultry vaccines in Nepal used to be produced in fertile eggs available at local hatcheries. Since 1997, specific pathogen free (SPF) eggs have been used to produce poultry vaccines which was initiated with the financial support from Strengthening Veterinary Service for Livestock Disease Control (SVSLDC) project (Gautam et al., 2018). The heat stable vaccine against ND, i.e. NDI2, was produced in 2008 targeting the backyard poultry (Gautam et al., 2018; NVPL, 2019; NVPL, 2020).

At present, three different laboratories have been registered for poultry vaccine production in Nepal (Table 3) (Biovac, 2020; Hester, 2020). National Vaccine Production Laboratory (NVPL) is the government owned laboratory while Hester Biosciences Nepal and Biovac Nepal are private laboratories (Poudel et al., 2020). In recent years, private companies also have started production of vaccines in Nepal, but the production quantity and market share are not clear. The maximum supply of in-country produced vaccine so far is carried out by NVPL. As per NVPL's annual report (2018-2019), ND F1 strain; fowl pox and IBD; ND R2B and Lasota; and ND-I2 vaccine doses produced in the year 2018 were 15, 8, 5, and 1.96 million, respectively (Poudel et al., 2020).

Vaccines of many poultry diseases are not manufactured in Nepal and hence they are imported from foreign countries. In the year 2014-2015, 549 million doses of poultry vaccines were imported from foreign countries which increased by $>300 \%$ in $2018-2019$ as Nepal imported 2,378 million doses of poultry vaccines in that year (Figure 4) (Poudel et al., 2020). Vaccines imported from other countries may not necessarily provide protection against field strain of pathogens circulating in Nepal. Lack of proper cold chain maintenance during transportation might also play role in variable vaccine effectiveness. Moreover, there are not enough studies determining the field performance of various poultry vaccines in Nepal. These facts highlight the need for identifying the various circulating pathogens within the country, developing vaccines targeting the circulating strains of pathogens, and performing vaccine efficacy studies periodically.

\section{Economic Aspects and Distribution of Poultry Vaccines}

Cost of feed, chicks, medicines, and vaccines are the major expenses in the poultry industry of Nepal (CBS, 2016). On average, $62.3 \%$ of the 
poultry farmers in Nepal depend on loan out of which $45 \%$ need loans for housing, $30 \%$ for buying chicks, $19.9 \%$ for feed, $2.3 \%$ for vaccine, and $1 \%$ for machinery (CBS, 2016). The cost of vaccine also plays significant role in the farmers economy and return on investment. Large commercial farms import different types of vaccines from other countries regardless of the cost of vaccines which increases the cost of poultry production. At the same time, small-scale farmers do not have access to such vaccines leaving their birds at risk of infection. Thus, there is a need for producing different types of poultry vaccines within the country and make them available at lower price to all poultry farmers. NVPL supplies quality and effective vaccines against certain diseases (Table 3 ) in nominal price to the farmers. Before 1989, NVPL used to distribute vaccines free of cost to the farmers but after 1989 it started to charge certain nominal price (NVPL, 2020). These vaccines are either supplied at low cost through the stockiest or provided free of cost through National Animal Disease Control Program (NADCP). NVPL should increase the types and quantity of vaccines which will be easily accessible and affordable to farmers.

Table 3. Poultry vaccines manufactured in Nepal (Biovac, 2020; Hester, 2020; NVPL, 2019).

\begin{tabular}{|c|c|c|c|}
\hline Manufacturer & Disease & Type & Vaccine \\
\hline $\begin{array}{l}\text { Biovac Nepal Private } \\
\text { Limited }\end{array}$ & Newcastle disease & Live & ND I-2 vaccine \\
\hline $\begin{array}{l}\text { Hester Biosciences } \\
\text { Nepal Private }\end{array}$ & Newcastle disease & Live & $\begin{array}{l}\text { Newcastle disease } \\
\text { LaSota strain vaccine }\end{array}$ \\
\hline \multirow[t]{5}{*}{ Limited } & IBD & Live & $\begin{array}{l}\text { Infectious bursal } \\
\text { disease Winterfield } \\
2512 \text { strain vaccine }\end{array}$ \\
\hline & Fowl typhoid & Live & $\begin{array}{l}\text { Fowl typhoid } \\
\text { Salmonella gallinarum } \\
\text { 9R strain vaccine }\end{array}$ \\
\hline & IB & Live & $\begin{array}{l}\text { Avian infectious } \\
\text { bronchitis } 4 / 91 \text { type } \\
\text { strain vaccine }\end{array}$ \\
\hline & Marek's disease & Live & $\begin{array}{l}\text { Marek's disease } \\
\text { frozen rispens strain } \\
\text { vaccine }\end{array}$ \\
\hline & Hydropericardium & Inactivated & $\begin{array}{l}\text { Inclusion body } \\
\text { hepatitis adenovirus } \\
\text { type } 4 \text { strain vaccine }\end{array}$ \\
\hline $\begin{array}{l}\text { National Vaccine } \\
\text { Production }\end{array}$ & Newcastle disease & Live & $\begin{array}{l}\text { Newcastle disease F1 } \\
\text { strain vaccine }\end{array}$ \\
\hline \multirow[t]{4}{*}{ Laboratory } & Newcastle disease & Live & $\begin{array}{l}\text { Newcastle disease } \\
\text { LaSota strain vaccine }\end{array}$ \\
\hline & Newcastle disease & Live & $\begin{array}{l}\text { Newcastle disease I- } 2 \\
\text { strain vaccine }\end{array}$ \\
\hline & Newcastle disease & Live & $\begin{array}{l}\text { Newcastle disease } \\
\text { R2B strain vaccine }\end{array}$ \\
\hline & $\begin{array}{l}\text { Fowl pox } \\
\text { IBD }\end{array}$ & $\begin{array}{l}\text { Live } \\
\text { Live }\end{array}$ & $\begin{array}{l}\text { Fowl pox vaccine } \\
\text { IBD intermediate } \\
\text { strain vaccine }\end{array}$ \\
\hline
\end{tabular}

\section{Poultry Vaccines to Reduce Use of Antibiotics}

Use of antibiotics in the poultry sector during the past 50 years has helped the growth of the industry by preventing negative impact of various bacterial diseases (Mehdi et al., 2018). In Nepal, most of the poultry production is done in intensive farming system (CBS, 2016; FAO, 2014a). Government of Nepal has released National Antibiotics Treatment
Guidelines in 2014 to address the issues of antimicrobial resistance and commenced policies for no antibiotics in feed supplements. Antibiotics were used as a growth promoter in animal feed, but recently MoALD has banned the use of antibiotic feed supplement as a growth promoter in feed; however, there are no alternatives of antibiotics for the prevention and treatment of animal diseases except some use of prebiotics, probiotics, and photoactive molecules. Top seven antibiotics used in veterinary sector in Nepal are tetracycline, enrofloxacin, neomycin, doxycycline, levofloxacin, colistin and tylosin and the most inappropriately prescribed antibiotics are ampicillin, amoxicillin, ceftriaxone and gentamicin (Acharya \& Wilson, 2019). Many poultry farmers in villages give self-medication of antibiotics and the indiscriminate use of antibiotics without proper drug sensitivity testing leads to the development of antibiotic resistance in the bacteria. The supply of poultry meat and eggs in the market without proper withdrawal period leads to the presence of antibiotic residues. Antibiotic residues present in the manure used for agricultural crops eventually reaches to humans as end consumer of agricultural products through biomagnification. Effective use of vaccines can prevent poultry infections from different pathogens as well as delay the resistance development in pathogens against these antibiotics (Marangon \& Busani, 2006). Therefore, development and use of vaccines against different bacterial pathogens of poultry can also contribute towards the reduction of antibiotic resistance problem in poultry sector protecting poultry as well as human health.

Figure 4. Import of poultry vaccines in Nepal from 2014/15 - 2018/19

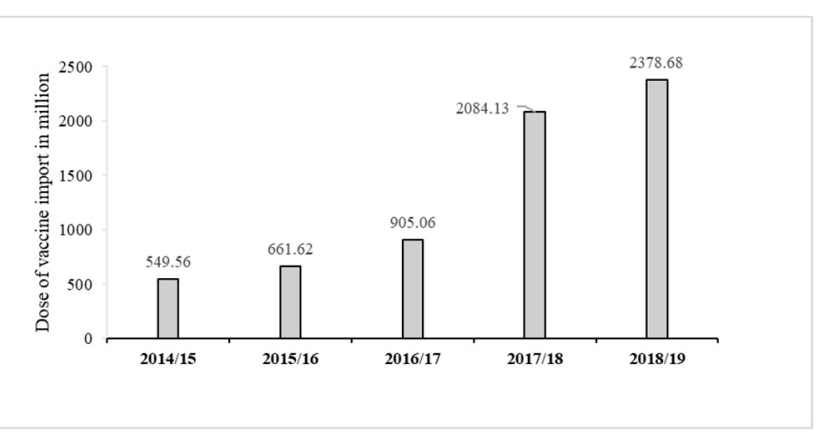

(VSDRL, 2020).

\section{Poultry Vaccine Production Issues in Nepal}

Though various poultry vaccines are being used continuously in Nepal, data are lacking regarding their immunogenicity and efficacy in the field. Vaccines should match with field strains of viruses, bacteria, or parasites to be efficacious and if not, they need to be upgraded. However, mechanisms to continuously monitor field strains of viruses, bacteria, and parasites in poultry are lacking in Nepal. This becomes even more important with imported vaccines as they may not necessarily provide cross-reactive immunity and cross-protective mechanisms against pathogens that are specifically adapted to microclimatic conditions of Nepal. Lack of resources, e.g., the specific pathogen free (SPF) eggs and animal experimental units, limit the proper testing and evaluation of these vaccines before their commercial use. With increased poultry production, it is apparent that the demand for poultry vaccines will also increase. Therefore, the Government of Nepal should scale up its existing poultry vaccine production capabilities. For this, human resource capacity building and use of latest updated technologies should be considered. A strong research 
mechanism should be established to continuously monitor the pathogen diversity and evolution within the country and to evaluate field efficacy of in-country produced or imported vaccines.

\section{Conclusion}

Poultry industry is one of the booming industries in Nepal. Investment in poultry industry in the past decade has significantly contributed to the national economy and has created employment opportunities for significant population. As a result of the ongoing pandemic of coronavirus disease (COVID-19), many Nepali citizens are returning home after losing their foreign employments. It is highly likely that agriculture and more specifically poultry farming will be one of the major attractions to them. Hence, poultry population and production are likely to increase in coming years. Outbreaks of various poultry diseases frequently suggest the need for regular monitoring and surveillance of poultry diseases and development of effective vaccines against them. Despite the continuous efforts from NVPL, poultry vaccines being produced within the country are not adequate and millions of doses of vaccines are being imported each year. Imported vaccines may not efficiently work as they may not match with the prevailing strains or subtypes of pathogens within the country. Hence, better understanding of the behavior and ecology of prevailing pathogens within the country is necessary. Changing pathogen characteristics may demand for changes in vaccine formulations. Research work should be improved in Nepal to quantify whether the existing vaccines, either manufactured within the country or imported, are working efficiently. More investment from both governmental and non-governmental sectors is necessary for research and development of novel adjuvants and improved vaccine formulations. Regular monitoring and supervision of vaccine production system, cold chain maintenance, and safety and quality standards should be done to reduce chances of vaccine failures. Government and private sectors should work together to make Nepal selfreliant in poultry vaccine production.

\section{References}

Acharya, K. P., \& Kaphle, K. (2015). Major Issues for Sustainable Poultry Sector in Nepal: A REVIEW. Global Journal of Animal Scientific Research, 3(1), 227-239. Retrieved January 23, 2021, from http://archives.gjasr.com/index.php/GJASR/article/view/149

Acharya, K. P., \& Wilson, R. T. (2019). Antimicrobial Resistance in Nepal. Frontiers in Medicine, 6, 1-10. https://doi.org/10.3389/fmed.2019.00105

Ae, Z. J., Wilson, J. P., David, A. E., Ae, M. W., Casper, H. H., Jurjevic, Z., ... Casper, H. H. (2007). Changes in fungi and mycotoxins in pearl millet under controlled storage conditions. Springer, 164(5), 229-239. https://doi.org/10.1007/s11046-007-9042-7

Arihara, K. (2006). Strategies for designing novel functional meat products. Meat Science, 74, 219-229. https://doi.org/10.1016/j.meatsci.2006.04.028

Aryal, S. R., \& Karki, D. (2009). Prevalence of aflatoxin B1 and B2 in poultry feed. Nepal Agriculture Research Journal, 9, 192-195. Retrieved from http://narc.gov.np/publicaton/pdf

Biovac. (2020). Vaccine Research, Development and Production. Retrieved April 10, 2021, from https://biovacnepal.com/

CBS. (2016). Summary Report \& Major Findings Nepal Commercial Poultry Survey 2071/72. Thapathali, kathmandu, Nepal. Retrieved from https://www.scribd.com/document/347608850/Nepal-Commercial-PoultrySurvey-2071-72
CVL. (2015). Annual Technical Report 2014/15. Retrieved May 10, 2020, from http://www.cvl.gov.np/uploads/files/5324820354.pdf

Dale, E., \& Brown, C. (2013). Zoonotic diseases from poultry. Brazilian Journal of Veterinary Pathology, 6(2), 76-82.

Dhakal, R., Joshi, B., Karn, R., Bhusal, S., \& Acharya, B. (2019). A Review on Scenario, Challenges and Prospects of Poultry Production in Nepal. Malaysian Journal of Sustainable Agriculture, (November), 60-63. https://doi.org/10.26480/mjsa.02.2019.60.63

DLS. (2021). Department of Livestock Services, Act and Policies. Retrieved February 13, 2021, from http://www.dls.gov.np/downloadsdetail/4/2018/41339141

FAO. (2006). World agriculture: towards 2030/2050 Prospects for food, nutrition, agriculture and major commodity groups. FAO, (June), 78.

FAO. (2014a). Poultry Sector Nepal. In FAO Animal Production and Health Livestock Country Reviews. No. 8. 4-16.

FAO. (2014b). Decision tools for family poultry development. FAO Animal Production and Health Guidelines No. 16, FAO., Rome, Italy. Retrieved May 10, 2020, from http://www.fao.org/3/a-i3542e.pdf

FAO. (2020a). Gateway to poultry production and products. Retrieved May 7 , 2020, from http://www.fao.org/poultry-production-products/production/en/

FAO. (2020b). Nepal at a glance, FAO in Nepal. Retrieved May 9, 2020, from http://www.fao.org/nepal/fao-in-nepal/nepal-at-a-glance/en/

Farrell, D. (2013). The role of poultry in human nutrition. FAO, 1-3. Retrieved May 10, 2020, from http://www.fao.org/3/al709e/al709e00.pdf

Gautam, G., Devekota, B., \& Thapaliya, S. (2017). Recent Case Flow Pattern in Veterinary Teaching Hospital of Agriculture And Forestry University, Chitwan, Nepal. Journal of Agriculture and Forestry University, 1, 119128.

Gautam, S. P., Ghimire, N. P., Shrestha, S., \& Gautam, S. (2018). History of Vaccine Production and Vaccination in Nepal. Golden Jubilee Souvenir, 1(1), 136-143.

Gerber, P., Opio, C., \& Steinfeld, H. (2007). Poultry production and the environment-A review. FAO, 1-27. Retrieved from http://www.fao.org/ag/againfo/home/events/bangkok2007/docs/part2/2_2.p df

Gompo, T. R., Pokhrel, U., Shah, B. R., \& Bhatta, D. D. (2019). Epidemiology of Important Poultry Diseases in Nepal. Nepalese Veterinary Journal, 36, 8-14. https://doi.org/10.3126/nvj.v36i0.27746

Gupta, A. R. (2011). Ascites syndrome in poultry: a review. Worlds Poultry Science Journal, 67(3), 457-468.

Hester. (2020). POULTRY LIVE VACCINES AND HEALTH PRODUCTS. Retrieved May 11, 2020, from https://www.hester.com.np/poultry-products

Marangon, S., \& Busani, L. (2006). The use of vaccination in poultry production. In Rev. sci. tech. Off. int. Epiz (Vol. 26), 265-274. Retrieved from https://www.oie.int/doc/ged/D4243.PDF

McVey, S., \& Shi, J. (2010). Vaccines in Veterinary Medicine: A Brief Review of History and Technology. Veterinary Clinics of North America - Small Animal Practice, Vol. 25, pp. 219-232. https://doi.org/10.1016/j.cvsm.2010.02.001

Mehdi, Y., Létourneau-Montminy, M. P., Gaucher, M. Lou, Chorfi, Y., Suresh, G., Rouissi, T., ... Godbout, S. (2018). Use of antibiotics in broiler production: Global impacts and alternatives. Animal Nutrition, Vol. 4, pp. 170-178. https://doi.org/10.1016/j.aninu.2018.03.002

MoALD. (2020). Nepal Agriculture Statistics 2017/18. Retrieved May 9, 2020, from https://www.moald.gov.np/publication/Agriculture Statistics

Mottet, A., \& Tempio, G. (2017). Global poultry production: Current state and future outlook and challenges. World's Poultry Science Journal, 73(2), 245-256. https://doi.org/10.1017/S0043933917000071

Murphy, S. P., \& Allen, L. H. (2003). Animal Source Foods to Improve Micronutrient Nutrition and Human Function in Developing Countries. J. Nutr, 133(February), 3932-3935.

NVPL. (2019). Annual Report 2075/76. National Vaccine Production Laboratory, Tripureshwor, Kathmandu. 1, 45.

NVPL. (2020). Vaccine and Production Year. Retrieved May 10, 2020, from http://nvpl.gov.np/ 
OECD-FAO. (2011). OECD-FAO Agricultural Outlook 2011-2020. Retrieved July 23, 2020, from https://thepoultrysite.com/articles/oecdfao-agriculturaloutlook-20112020

Olaoye, O. A. (2011). Meat: An overview of its composition, biochemical changes and associated microbial agents. International Food Research Journal, 18(3), 877-885.

Osti, R., Bhattarai, D., Chaudhary, H., \& Singh, V. (2017). Poultry Production in Nepal: Characteristics, Productivity and Constraints. International Journal of Applied Sciences and Biotechnology, 5(2), 222-226. https://doi.org/10.3126/ijasbt.v5i2.17616

Petracci, M., Bianchi, M., Mudalal, S., \& Cavani, C. (2013). Functional ingredients for poultry meat products. Trends in Food Science and Technology, 33(1), 27-39. https://doi.org/10.1016/j.tifs.2013.06.004

Poudel, U., Dahal, U., Upadhyaya, N., Chaudhari, S., \& Dhakal, S. (2020). Livestock and Poultry Production in Nepal and Current Status of Vaccine Development. Vaccines, 8(2), 322 https://doi.org/10.3390/vaccines8020322

Pradhanang, U., Pradhanang, S., Sthapit, A., Krakauer, N., Jha, A., \& Lakhankar, T. (2015). National Livestock Policy of Nepal: Needs and Opportunities. Agriculture, 5(1), 103-131. https://doi.org/10.3390/agriculture5010103

Prasain, S. (2021, March 25). Nepal becomes self-sufficient in egg and meat production. The Kathmandu Post. Retrieved April 10, 2021 from https://kathmandupost.com/money/2021/03/25/nepal-becomes-selfsufficient-in-egg-and-meat-production

Rajkumar, S., Reddy, M., \& Tech, R. S. (2017). Incidence and risk factors of chronic respiratory disease in Indian poultry flocks. International Journal of
Science, Environment and Technology, 6(1), 662-668. Retrieved from http://www.ijset.net/journal/1590.pdf

Sharma, B. (2010). Poultry Production, Management and Bio-Security Measures. Journal of Agriculture and Environment, 11, 120-125. https://doi.org/10.3126/aej.v11i0.3659

Shrestha, A. (2019, May 3). First bird flu death reported in Nepal. The Himalayan Times. Retrieved May 10, 2020. from https://thehimalayantimes.com/nepal/first-bird-flu-death-reported-in-nepal/

Shrestha, S., \& Shrestha, B. K. (2020). CASE-FLOW ANALYSIS OF NATIONAL AVIAN DISEASE INVESTIGATION LABORATORY (NADIL), CHITWAN DURING AUGUST 2016 TO JANUARY 2017. Retrieved May 10, 2020, from https://www.farm.com.np/research/poultrydisease-in-nepal/

Singh, S. (2018). Overview of Nepalese Poultry Industry. Retrieved January 23, 2021, from http://www.vcn.gov.np/uploads/files/Overview of Nepalese Poultry Industry_Dr_Subir.pdf

Spradbrow, P. (1992). Newcastle Disease in Village Chickens Control with Thermostable Oral Vaccines. Proceedings of an International Workshop Held in Kuala Lumpur, Malaysia, 6-10 October 1991, (39), 189.

VEC. (2018). National Annual Disease Report. Annual epidemiological bulletin January-December 2018. Animal disease investigation and control division, Tripureshwor, Kathmandu, Nepal.14, 38.

VSDRL. (2020). Annual Progress and Technical Report-2018/19. Retrieved January 24, 2021, from http://www.vsdrl.gov.np/downloadsdetail/3/2018/44178961 